\title{
Damien Agut-Labordère. "Oil and wine for silver? The economic agency of the Egyptian peasant communities in the Great Oasis during the Persian Period"
}

\section{Sépideh Qaheri-Paquette}

\section{(2) OpenEdition}

\section{Journals}

Édition électronique

URL : http://journals.openedition.org/abstractairanica/47294

DOI : $10.4000 / a b s t r a c t a i r a n i c a .47294$

ISBN : 1961-960X

ISSN : 1961-960X

Éditeur :

CNRS (UMR 7528 Mondes iraniens et indiens), Éditions de l'IFRI

\section{Référence électronique}

Sépideh Qaheri-Paquette, « Damien Agut-Labordère. "Oil and wine for silver? The economic agency of the Egyptian peasant communities in the Great Oasis during the Persian Period" », Abstracta Iranica [En ligne], Volume 37-38-39 | 2018, document 93, mis en ligne le 30 décembre 2018, consulté le 02 octobre 2020. URL : http://journals.openedition.org/abstractairanica/47294 ; DOI : https://doi.org/ 10.4000/abstractairanica.47294

Ce document a été généré automatiquement le 2 octobre 2020.

Tous droits réservés 


\title{
Damien Agut-Labordère. "Oil and wine for silver? The economic agency of the Egyptian peasant communities in the Great Oasis during the Persian Period"
}

\author{
Sépideh Qaheri-Paquette
}

\section{RÉFÉRENCE}

Damien Agut-Labordère. "Oil and wine for silver? The economic agency of the Egyptian peasant communities in the Great Oasis during the Persian Period" in J.C. Moreno García (ed.). Dynamics of production in the ancient Near East: 1300-500 BC. Oxford-

Philadelphia: Oxbow books, 2016, p. 41-52

1 Les plus anciennes attestations écrites en Égypte des statères d'argent dans la documentation démotique d"Ayn Manāwir (412-410 av. J.-C.), mène l'auteur à s'interroger dans cet article sur les dynamiques économiques de l'oasis de Kharga à l'époque perse. La position de la communauté oasienne dans les éventuels réseaux d'échanges monétaires avec la Vallée du Nil est ici évaluée à travers la capacité d'exportation des produits locaux. Dans ce sens, l'A. rappelle les contenants en céramique (en particulier les siga) mais notamment les productions végétales, i.e. le vin et l'huile de ricin, dont l'importance dans l'économie villageoise à 'Ayn Manāwir peut être confirmée d'après les données textuelles et/ou archéobotaniques recueillies sur le site. 


\section{AUTEURS}

\section{SÉPIDEH QAHERI-PAQUETTE}

Université Lyon 2 